\title{
The protective and anti-inflammatory effect of methylene blue in corrosive esophageal burns: An experimental study
}

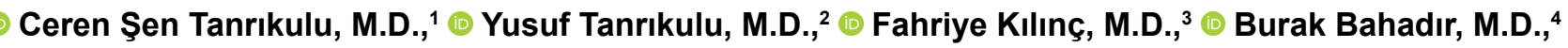 \\ Murat Can, M.D., ${ }^{5}$ @ Fürüzan Köktürk, M.D., ${ }^{6}$ ๑ Ayşe Kefeli, M.D. ${ }^{7}$
}

\author{
1'Department of Emergency Medicine, Health Sciences University, Konya Training and Research Hospital, Konya-Turkey \\ ${ }^{2}$ Department of General Surgery, KTO Karatay University Faculty of Medicine, Konya-Turkey \\ ${ }^{3}$ Department of Pathology, Necmettin Erbakan University Faculty of Medicine, Konya-Turkey \\ ${ }^{4}$ Department of Pathology, Bülent Ecevit University Faculty of Medicine, Zonguldak-Turkey \\ ${ }^{5}$ Department of Biochemistry, Bülent Ecevit University Faculty of Medicine, Zonguldak-Turkey \\ ${ }^{6}$ Department of Biostatistics, Bülent Ecevit University Faculty of Medicine, Zonguldak-Turkey \\ ${ }^{7}$ Department of Gastroenterology, Gaziosmanpasa University Faculty of Medicine, Tokat-Turkey
}

\begin{abstract}
BACKGROUND: In developing countries, esophageal burns are quite common. They are caused by the ingestion of corrosive substances that may lead to esophageal perforation in the short-term and stricture formation in the long-term. Prevention of stricture progression in the esophagus is the main aim of the treatment for corrosive esophageal burns. We aimed to investigate the protective and anti-inflammatory effects of methylene blue (MB) treatment on corrosive esophageal burns.
\end{abstract}

METHODS: Twenty-eight rats were used in the study and randomly divided into four equal groups; group I (Sham), group 2 (control), group 3 (topical treatment), and group 4 (topical plus systemic treatment). Except for group I (Sham group), all three groups received sodium hydroxide $(\mathrm{NaOH})$ in order to generate esophageal burns. In addition, group 2 was given normal saline, group 3 topical MB, and group 4 topical and systemic $\mathrm{MB}$.

RESULTS: Hydroxyproline levels were found to be lower in each of the treatment groups as compared to the control group ( $p=0.005$ for group 3 and $p=0.009$ for group 4). There were no differences in the tumor necrosis factor- $\alpha$ (TNF- $\alpha$ ) levels between the groups. The stenosis index $(\mathrm{SI})$ in the treatment groups was also lower than the control group $(p=0.016$ for group 3 and $p=0.015$ group 4$)$. The histopathologic damage score (HDS) was prominently lower in group 4 as compared to the control group $(p=0.05)$.

CONCLUSION: MB is effective in treating tissue damage caused by corrosive esophageal burns and in preventing esophageal stenosis. Complication rates of corrosive esophageal burns may be decreased by using MB in the initial treatment stage.

Keywords: Caustic burn; corrosive esophageal burn; methylene blue; stenosis index; TNF- $\alpha$.

\section{INTRODUCTION}

Corrosive esophageal burns, that mostly happen accidentally in children, constitute a serious problem across different age groups and are relatively common in rural areas and developing countries. ${ }^{[1]}$ Corrosive esophageal burns are caused by alkaline substances in $90 \%$ of cases and by acidic substances in the remaining $10 \% .{ }^{[2]}$ Alkaline substances are easily acces- sible since they are used for cleaning, soap making, or fruit drying.

The amount, concentration, and structure of the compound be it liquid or solid and the duration of the contact between the product and esophageal mucosa plays a critical role in the severity of the injury. The complications seen after the ingestion may vary from acute esophageal perforation to chronic

Cite this article as: Şen Tanrıkulu C, Tanrıkulu Y, Kılınç F, Bahadır B, Can M, Köktürk F, et al. The protective and anti-inflammatory effect of methylene blue in corrosive esophageal burns: An experimental study. Ulus Travma Acil Cerrahi Derg 2019;25:317-323.

Address for correspondence: Yusuf Tanrıkulu, M.D.

KTO Karatay Üniversitesi Tıp Fakültesi, Genel Cerrahi Anabilim Dalı, 42020 Konya, Turkey

Tel: +90 332 - 2210000 E-mail: drtanrikulu@hotmail.com

Ulus Travma Acil Cerrahi Derg 2019;25(4):317-323 DOI: 10.5505/tjtes.2018.58506 Submitted: 28.06.2018 Accepted: 16.1I.2018 Online: 08.07.2019

Copyright 2019 Turkish Association of Trauma and Emergency Surgery 
fibrosis leading to strictures. ${ }^{[3-5]}$ The aims of the treatment for corrosive esophageal burns are to improve wound healing, prevent perforation, and reduce stricture formation. There is a close connection between the severity of the initial injury and the stricture formation, which is a significant complication of corrosive esophageal burns. Therefore, the initial treatment may play a game-changing role in preventing the development of strictures. ${ }^{[6-8]}$ Since stricture formation is a consequence of the inflammation and fibrosis that occurs during wound healing, medical treatment should focus on reducing the wound inflammation. ${ }^{[9]}$ Although many agents, including retinoic acid, pentoxifylline, sucralfate, $\mathrm{N}$-acetylcysteine, antibiotics, and steroids have been used in both clinical and experimental studies to prevent the development of strictures, only antibiotics and steroids have gained clinical application. ${ }^{[10-13]}$

$M B$ was first identified as an antimalarial agent by Ehrlich in 1981, and it has since been used in many different areas of clinical medicine including treatment of refractory distributive shock, renal stones, carbon monoxide poisoning, methemoglobinemia, and encephalopathy for years due to its low toxicity and wide availability. ${ }^{[14,15]}$ Most recently, MB was described as an effective product for preventing postoperative adhesions as well. Although the mechanism is unknown, the anti-adhesive effect of MB may depend on the reduction of the anti-inflammatory products caused by trauma and antioxidant effects, such as the inhibition of the effect of nitric oxide (NO) and activation of fibrinolytic activity. ${ }^{[16,17]}$

Based on the literature describing the anti-adhesive effect of $M B$, we aimed to investigate the effect of $M B$ treatment on corrosive esophageal burns.

\section{MATERIALS AND METHODS}

\section{Study Design and Animals}

Each experiment was performed based on the National Guidelines for The Use and Care of Laboratory Animals after obtaining the approval of the Animal Ethics Committee of Bulent Ecevit University (number: 2014/I2). Twenty-eight male adult Wistar-Albino rats, weighing $250 \pm 30 \mathrm{~g}$, were housed individually under constant temperature $\left(2 \mathrm{I} \pm \mathrm{I}{ }^{\circ} \mathrm{C}\right)$ in wire cages with 12-hour light-dark cycles, fed a standard diet, and given water ad libitum. The animals were deprived of food from 12 hours before anesthesia. However, no water restriction was done until 2 hours before anesthesia. No enteral or parenteral antibiotics were administered at any time.

\section{Experimental Model}

The experimental corrosive esophageal burns were induced according to the model described by Gehanno et al. ${ }^{[18]}$ in 1981. All the animals were sedated using $80 \mathrm{mg} / \mathrm{kg}$ ketamine hydrochloride (KetalarR; Parke-Davis, Istanbul, Turkey) and $20 \mathrm{mg} / \mathrm{kg}$ xylazine (RompunR, Bayer, Istanbul, Turkey) intramuscularly. In this study, a $1.5 \mathrm{~cm}$ distal esophageal segment was used to administer the burns. Following a median laparotomy, a five Fr catheter was inserted through the mouth and placed into the distal esophagus. To prevent the escape of the solution directly into the stomach or into the respiratory tract by aspiration, the cardio-esophageal junction and proximal esophagus were tied with $2 / 0$ silk. A solution of $0.1 \mathrm{~mL}$ of $37.5 \%$ sodium hydroxide $(\mathrm{NaOH})$ was administered for 90 seconds and then aspirated. Next, the burned segments were washed using distilled water for 30 seconds. After cutting the sutures, the gastric insertion sites were also repaired. Following the closure of the laparotomy, $10 \mathrm{~mL}$ of $0.9 \%$ saline was administered intraperitoneally, and the rats were made to fast for the next 24 hours. The treatment of the study groups started on the first postoperative day. The rats were observed under standard laboratory conditions by feeding standard food and water ad libitum during the treatment period. No rats died during the experiment.

\section{Experimental Groups}

Twenty- eight rats were randomly divided into four groups ( 7 rats in each group):

Group I (Sham): A corrosive esophageal burn was not created after laparotomy. A $0.1 \mathrm{~mL}$ dose of saline was administered intraperitoneally to each rat as a single daily dose for ten days.

Group 2 (Control): A corrosive esophageal burn was created after laparotomy. A $0.1 \mathrm{~mL}$ dose of saline was administered intraperitoneally to each rat as a single daily dose without any treatment for ten days and the esophageal lumen was washed with a $0.1 \mathrm{~mL}$ dose of saline.

Group 3 (Topical Treatment): A corrosive esophageal burn was created after laparotomy. After washing the esophageal lumen with saline, a $0.1 \mathrm{~mL}$ dose of $\mathrm{I} \% \mathrm{MB}$ was administered topically to the esophageal lumen. The rats were placed in the reverse Trendelenburg position for 30 minutes to provide sufficient mucosal contact with the drug. Later, a $0.1 \mathrm{~mL}$ dose of saline was administered intraperitoneally to each rat as a single daily dose for ten days.

Group 4 (Topical+Systemic Treatment): A corrosive esophageal burn was created after laparotomy. After washing the esophageal lumen with saline, a $0.1 \mathrm{~mL}$ dose of $1 \%$ MB was administered topically to the esophageal lumen. The rats were placed in the reverse Trendelenburg position for 30 minutes to provide sufficient mucosal contact with the drug. Later, a $0.1 \mathrm{~mL}$ dose of $1 \% \mathrm{MB}$ was administered intraperitoneally to each rat as a single daily dose for ten days.

\section{Histopathological Evaluation}

One well-experienced pathologist who was blinded to the study design evaluated each specimen. For this evaluation, 2 $\mathrm{cm}$ distal esophagus sections were taken. A solution of $10 \%$ 
neutral formaldehyde was used to fix the esophageal tissue samples and followed by the paraffin embedding technique. Tissue samples of $4 \mu \mathrm{m}$ thickness were stained using hematoxylin-eosin (H\&E) and then analyzed under a light microscope (Olympus BX53, Tokyo, Japan).

Stenosis index (SI) was chosen to assess the degree of stenosis of the esophageal lumen in our study. For this evaluation, esophageal wall thickness was measured in two different areas from the mucosal surface to the connective tissue outside the muscularis propria using a millimetric ocular microscope and the average of the two measurements was calculated (AO $=[A I+A 2] / 2)$. The lumen diameters were also measured in two different areas along a straight line, and the average of the two measurements was obtained $(B 0=[B I+B 2] / 2)$. The $\mathrm{SI}$ was calculated as follows: $\mathrm{SI}=($ wall thickness $[\mathrm{A} 0]) /$ lumen diameter [B0]). ${ }^{[19]}$

The histopathologic damage score (HDS) was used to determine the degree of damage and collagen accumulation in the esophageal wall. The tissues were scored on a scale in three different categories for a total score of 0-5 (Table I). ${ }^{[20]}$ For this evaluation, the sections obtained from the paraffin-embedded tissue were stained with Masson's trichrome in order to evaluate changes in the connective tissue.

\section{Biochemical Analysis}

The spectrophotometric method was used to detect tissue hydroxyproline concentrations and the results were given as micrograms per milligram of tissue. ${ }^{[2]}$ The serum TNF- $\alpha$ levels were assessed using the Rat TNF- $\alpha$ ELISA kit (Eastbio-

Table I. Histopathological evaluation criteria

Criteria Score

Increase in submucosal collagen

None

Mild (submucosal collagen at least twice the

thickness of muscularis mucosa)

Severity (submucosal collagen more than twice

the thickness of muscularis mucosa)

Damage to the muscularis mucosa

None

Present

Damage and collagen deposition in tunica

muscularis

None

Mild (collagen deposition around the

smooth muscle fibers)

Severity (same as mild with collagen deposits replacing some muscle fibers) pharm, Hangzhou) as described in the instruction book. First, the samples, standards, and streptavidin-HRP were added to the well. The antibodies were labeled with an enzyme and the plate was incubated for 60 minutes at $37^{\circ} \mathrm{C}$. The plate was washed five times and chromogen solutions were added. The plate was incubated for 10 minutes at $37^{\circ} \mathrm{C}$ and the stop solution was added into the wells. The optical density (OD) was measured under $450 \mathrm{~nm}$ wavelengths with a microplate reader. According to standards concentration, the corresponding $O D$ values were calculated using the standard curve linear regression equation to calculate the corresponding sample's concentration.

\section{Statistical Analysis}

SPSS (Statistical Package for Social Science) for Windows 19.0 package program was used to analyze the results. The onesample Kolmogorov-Smirnov test was performed for data normality and then for continuous variables, the KruskalWallis variance analysis was used. The continues variables were given as the mean \pm standard deviation. Dunn's test was used as the post hoc test after the Kruskal-Wallis test. Noncontinuous variables were expressed as the median (minmax). To compare non-continuous variables, the Chi-Square test was used. A p-value of less than 0.05 was considered statistically significant for all tests.

\section{RESULTS}

The comparison of the levels of hydroxyproline and TNF- $\alpha$ among the groups are summarized in Table 2 . The levels of hydroxyproline were significantly lower in the treatment groups than in group 2 ( $p=0.005$ for group 3 and $p=0.009$ for group 4 ). The levels of TNF- $\alpha$ were lower in the treatment groups than in group 2 , however, these differences were not statistically significant ( $p=0.4 \mathrm{I} 3$ for group 3 and $p=0.444$ for group 4$)$.

The comparison between the esophageal stenosis assessments among the groups is given in Table 3 . There were no differences between the groups in terms of lumen diameters. The control group did not show a narrowing of the lumen diameter but showed an increase in wall thickness. The wall thicknesses in the treatment group were lower than in group 2 ; wall thickness in the group that systemically received $M B$ was closer to the sham group; and there was a difference in wall thickness between group 4 and group $2(p=0.023)$, but there was no difference between group 3 and group 2 $(p=0.687)$. According to the $\mathrm{Sl}$, there were differences between the treatment group and group $2(p=0.016$ for group 3 and $p=0.015$ group 4$)$.

The comparisons of the histopathological evaluations between groups are summarized in Table 3 and Fig. I. HDS was chosen as the method of evaluation in our study and was used to evaluate the increase in collagen deposition in the submucosal area and tunica muscularis and the destruction 
Table 2. The comparison of the levels of hydroxyproline and TNF- $\alpha$ between groups

\begin{tabular}{lcc}
\hline Groups & Hydroxyproline $(\mu \mathrm{g} / \mathbf{m g})$ & TNF- $\alpha$ (ng/L) \\
\hline Group I (SHAM) & $0.74 \pm 0.19^{\mathrm{c}}$ & $24.64 \pm 9.24$ \\
Group 2 (control) & $3.20 \pm 0.52$ & $53.93 \pm 8.87^{\times}$ \\
Group 3 (topical treatment) & $0.75 \pm 0.33^{\mathrm{a}}$ & $42.29 \pm 8.26$ \\
Group 4 (topical+systemic treatment) & $0.76 \pm 0.43^{\mathrm{b}}$ & $43.97 \pm 4.87$ \\
\hline
\end{tabular}

${ }^{\mathrm{a}} \mathrm{p}=0.005,{ }^{b} \mathrm{p}=0.009$ and $\mathrm{c} p=0.013$ vs. group $2,{ }^{\mathrm{x}} \mathrm{p}<0.001$ vs. group $\mathrm{I}$.

Table 3. The comparison of the histopathological evaluation results between groups

\begin{tabular}{lccc}
\hline Groups & $\begin{array}{c}\text { Wall } \\
\text { thickness }(\boldsymbol{\mu})\end{array}$ & $\begin{array}{c}\text { Stenosis } \\
\text { index }\end{array}$ & $\begin{array}{c}\text { Total histopathologic } \\
\text { score }\end{array}$ \\
\hline Group I (SHAM) & $0.74 \pm 0.27$ & $0.42 \pm 0.12^{\mathrm{x}}$ & $0(0-1)^{*}$ \\
Group 2 (control) & $1.13 \pm 0.14$ & $0.72 \pm 0.17$ & $3(2-3)$ \\
Group 3 (topical treatment) & $0.88 \pm 0.19$ & $0.44 \pm 0.12^{\mathrm{y}}$ & $\mathrm{I}(0-2)$ \\
Group 4 (topical+systemic treatment) & $0.70 \pm 0.14^{\mathrm{a}}$ & $0.39 \pm 0.09^{\mathrm{z}}$ & $\mathrm{I}(0-1)^{\#}$ \\
\hline
\end{tabular}

${ }^{2} p=0.023$ vs. group $2,{ }^{x} p=0.032,{ }^{y} p=0.016$ and ${ }^{z} p=0.015$ vs. group $2,{ }^{*} p=0.005$ and ${ }^{\#} p=0.019$ vs. group 2 .

of muscularis mucosa. Sham group showed a normal histologic state and lumen diameter. Other groups showed variable rates of inflammatory cells in the esophagus wall with characterized reactions. There were no differences between the groups in the increase of submucosal collagen $(p=0.210)$. Damage to the muscularis mucosa was significantly lower in group 4 than group $2(p=0.043$ and $p=0.026$, respectively), but there was no difference between group 2 and group 3 . The total HDS was significantly lower in group 4 than in group 2 ( $p=0.019)$ (Fig. I).
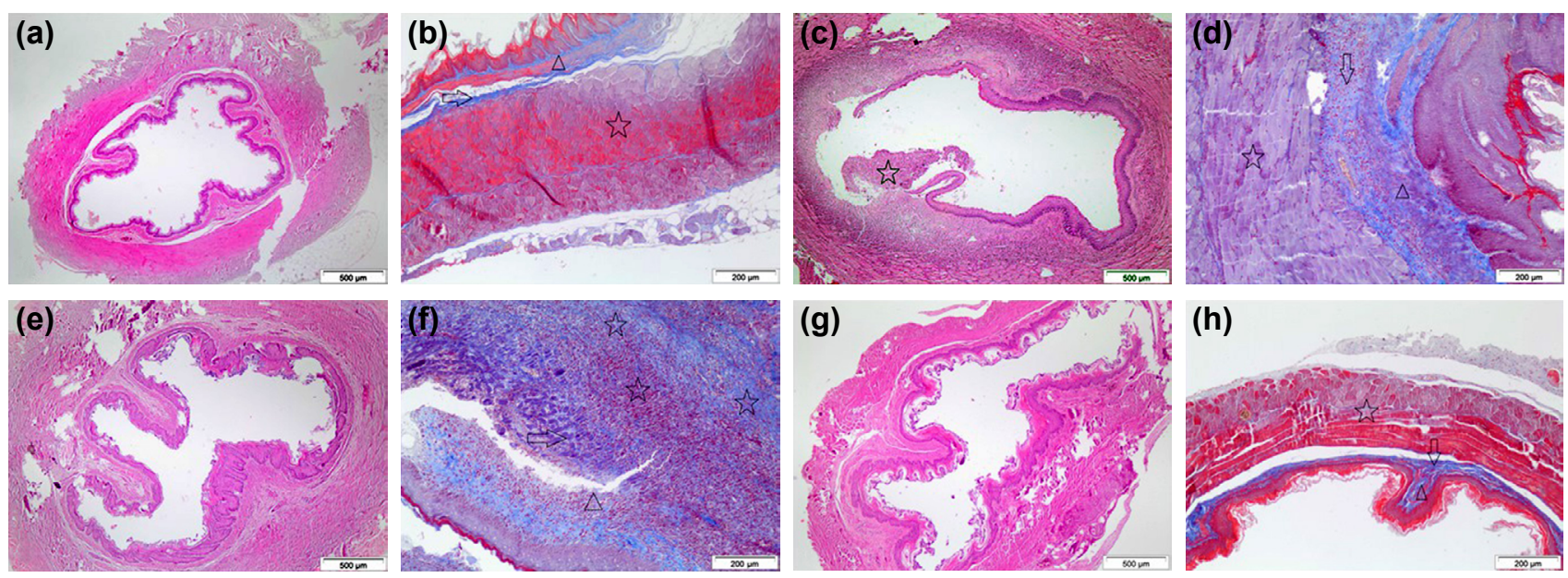

Figure 1. The sham group appears to have normal esophagus histology, lumen diameter, and wall thickness (a, b). The control group has contained focal inflammation cells that remove the epithelium (c). Muscularis mucosa and tunica muscularis are thickened, also the submucosal collagen is slightly increased (d). Topically treatment group (Group 3) has a normal lumen diameter (e) and deposition of collagen in the submucosa and muscularis tunica (f). Systemically treatment group (Group 4) appears to have normal lumen diameter and wall thickness (g). There was no histological damage except for a slight increase of collagen in the submucosa (h). In the Masson Trichrome figures; star shows the tunica muscularis layer, the arrow submucosal layer, and the triangle muscularis mucosa layer. For a, c, e, and $\mathrm{g}$ H\&E with $\times 40$ magnification; for b, d, f, and h Masson Trichrome with magnification $\times 100$ is used. 
Ingestion of caustic substances is a serious problem that causes corrosive esophagitis in the acute necrotic phase and stricture formation in the long-term. Therefore, the key to reducing these complications is a very good understanding of the pathophysiology. The level of damage varies based on the type of tissue affected, the amount of ingested substance, the period of contact, the type of agent (acid and alkali), and the physical structure (solid or liquid) of the caustic substance. ${ }^{[4]}$ Alkaline substances cause liquefaction necrosis, while acidic substances cause coagulation necrosis that is mostly limited to the mucosa. ${ }^{[22]}$ The acute necrotic phase occurs during the first 1-4 days following the injury and is characterized by decreased perfusion of the tissue, increased lipid peroxidation, hydrolysis, and reactive oxygen radicals and the beginning of the inflammatory reaction. Following the subacute phase, scar formation related to fibroblast proliferation and stricture formation related to collagen accumulation may occur. ${ }^{[12,22]}$

The medical treatment needs to reduce the inflammation because the degree of the acute inflammatory reaction plays the most important role in stricture formation. ${ }^{[23]}$ The current management protocol for corrosive esophagitis is still limited to antibiotics, steroids, and neutralization in the acute phase, although there are many other treatment methods that vary according to the phase and the severity of the damage. ${ }^{[9]}$ To reduce inflammation and collagen synthesis and to prevent fibroplasia and stricture formation, numerous studies have been performed to evaluate the medical efficiency of antioxidant and anti-inflammatory agents such as sucralfate, palifermin, dimethyl sulfoxide, prednisolone, retinoic acid, zinc, trimetazidine, and pentoxifylline. ${ }^{[9-13,22,23]}$ Despite the decreased stricture formation demonstrated in these studies, the rate of stricture formation is still $70-100 \%$ in high-grade corrosive esophagitis. ${ }^{[9]}$

$M B$, a nontoxic and safe dye, has both anti-adhesive and antiinflammatory properties. Although the main mechanism of action of $M B$ is unknown, the primary effect of $M B$ inhibits guanylate cyclase by targeting NO. The anti-adhesive effects of MB may depend on the reduction of the anti-inflammatory products caused by trauma and antioxidant effects such as inhibition of the effect of $\mathrm{NO}$ and the activation of the fibrinolytic activity. ${ }^{[17,24]}$ In addition, MB shows immunomodulatory effect by the expression of adhesion molecules on endothelial cells. MB reduced TNF production by $50 \%$ and inhibited the systemic and local inflammation. ${ }^{[25]}$ The main effect of MB in inflammation has not been fully clarified as of today and its mechanism should be analyzed further. Besides the anti-inflammatory effects of $M B$, it has antioxidant effects as well. In contrast to classic antioxidants like vitamin E, MB has a direct inhibitory effect on endogenous NADPH. ${ }^{[26]}$

On reviewing the literature, several studies can be found on the effect of MB. One of them was conducted by Kilincaslan et al., ${ }^{[27]}$ who found that MB applied locally might reduce the tissue damage in corrosive esophagitis because of its antiox- idant effects. In their studies on adhesions, Kalaycı et al. ${ }^{[17]}$ and Dinc et al. ${ }^{[16]}$ found that while MB may prevent peritoneal adhesions, it could wound healing could be impaired.

In a randomized retrospective study conducted by Gümürdülü et al.,", it was found that the prevalence of stricture formation could be reduced with sucralfate treatment. Howell et al. ${ }^{[28]}$ found that treatment of corrosive esophagitis with steroids decreased the frequency of stricture formation. In their study comparing beta-aminopropionitrile (BAPN) and prednisolone, Aciksari et al. ${ }^{[13]}$ found that BAPN was able to decrease the development of stenosis and tissue damage better than prednisolone. Şen Tanrıkulu et al. ${ }^{[29]}$ found that garlic oil is an effective agent in promoting the regression of esophageal stenosis and tissue damage caused by corrosive burns. In another study, ${ }^{[23]}$ investigators found that dimethyl sulfoxide may decrease the severity of tissue damage. In addition to inflammation, oxidative stress has a key role in increased tissue damage. It was shown that reactive oxygen radicals increased during the early phase of esophageal burns and that $\mathrm{NaOH}$ treatment increased lipid peroxidation. ${ }^{[19,30]}$ In corrosive esophageal burns, while $\mathrm{SI}$ and HDS are the most important indicators of esophagus damage, the levels of hydroxyproline are an indicator of collagen accumulation. These indicators are used to demonstrate the esophageal stricture and to evaluate the efficacy of therapeutic agents. ${ }^{[I]}$ In our study, we examined SI and HDS to evaluate esophageal damage, levels of hydroxyproline to evaluate collagen accumulation, and levels of TNF- $\alpha$ to evaluate the anti-inflammatory effect. We found that the levels of hydroxyproline were lower in the treatment groups than in the control group. Although the levels of TNF- $\alpha$ were lower in the treatment groups than in group 2, the differences were not significant. In addition, we found that there were differences in the SI results between treatments groups and the control group. The total HDS was significantly lower in group 4 than the control group $(p=0.019)$.

Unfortunately, the current results hardly suggest that we use $\mathrm{MB}$ in a clinical setting. In this rat model, we applied a constant quantity of $M B$ to the esophageal lumen via a catheter. In reality, the clinical use of $M B$ is poorly understood. $M B$ is mostly used as $10 \mathrm{mg} / \mathrm{ml}$ in the form of an ampoule as a pharmaceutical treatment for several diseases such as methemoglobinemia. ${ }^{[3]}$ In the daily clinical routine, MB doses of up to $7 \mathrm{mg} /$ $\mathrm{kg}$ have been used in humans in case of shock. ${ }^{[32]}$ The highest acceptable dose of $\mathrm{MB}$ is $9 \mathrm{mg} / \mathrm{kg}^{\left[{ }^{[33]}\right.}$ Although the optimal dose of this dye is not known, based on the present study results we concluded that a volume of $1 \%$ of $M B$ may reduce the level of stenosis. Finally, the ingestion of commercial bulb forms containing methylene blue per orally can be suggested after corrosive ingestion.

\section{Conclusions}

In this study, we found that MB administered topically and/ or systemically was an effective agent to treat tissue damage 
caused by corrosive burns and to prevent esophageal stenosis. This beneficial effect was more pronounced with systemic treatment. However, a significant anti-inflammatory effect of $M B$ was not detected. We believe that the use of $M B$ during the initial emergency clinic treatment of patients with corrosive esophageal burns could reduce complications such as stenosis and strictures. To assess the medical application of $\mathrm{MB}$, further comprehensive clinical studies are required.

\section{Acknowledgments}

Thanks are due to the employees of the operating room and the department of pathology.

Ethics Committee Approval: Ethics committee approval was received for this study from the Ethics Committee of Bulent Ecevit University Faculty of Medicine numbered 20I4/I2.

Financial Disclosure: The authors declared that this study has received no financial support.

\section{Conflict of interest: None declared.}

\section{REFERENCES}

1. Karaoglu AO, Ozutemiz O, Ilter T, Batur Y, Yonetci N, Tekesin O, et al. Caustic ingestion injuries: evaluation of 108 cases. Turk J Gastroenterol 1998;1:55-60.

2. Bautista A, Varela R, Villanueva A, Estevez E, Tojo R, Cadranel S. Effects of prednisolone and dexamethasone in children with alkali burns of the oesophagus. Eur J Pediatr Surg 1996;6:198-203. [CrossRef]

3. Millar AJW, Cywes S. Caustic strictures of esophagus. In: Pediatric Surgery. O'Neill JJ, Rowe MI, Grosfeld JL, et al, editors. St Louis: Mosby; 1998.p. 969-79.

4. Peters JH, De Meester TR. Esophagus and diaphragmatic hernia. Schwartz SI, Shires GT, Spencer FC, eds. Principles of Surgery. 7th edition. New York: McGraw-Hill; 1999.p.1158-61.

5. Ekingen G, Ozden M, Sözübir S, Maral H, Müezzinoğlu B, Kahraman $\mathrm{H}$, et al. Effect of the prostacyclin derivate iloprost in experimental caustic esophageal burn. Pediatr Surg Int 2005;21:441-4. [CrossRef]

6. Koltuksuz U, Mutuş HM, Kutlu R, Ozyurt H, Cetin S, Karaman A, et al. Effects of caffeic acid phenethyl ester and epidermal growth factor on the development of caustic esophageal stricture in rats. J Pediatr Surg 2001;36:1504-9. [CrossRef]

7. Cakmak M, Nayci A, Renda N, Erekul S, Gökçora H, Yücesan S. The effect of corticosteroids and pentoxifylline in caustic esophageal burns. A prospective trial in rats. Int Surg 1997;82:371-5.

8. Demirbilek S, Bernay F, Rizalar R, Bariş S, Gürses N. Effects of estradi$\mathrm{ol}$ and progesterone on the synthesis of collagen in corrosive esophageal burns in rats. J Pediatr Surg 1994;29:1425-8. [CrossRef]

9. Gümürdülü Y, Karakoç E, Kara B, Taşdoğan BE, Parsak CK, Sakman G. The efficiency of sucralfate in corrosive esophagitis: a randomized, prospective study. Turk J Gastroenterol 2010;21:7-11. [CrossRef]

10. Corduk N, Koltuksuz U, Calli-Demirkan N, Rota S, Abban G, Sarioglu-Buke A. Effects of retinoic acid and zinc on the treatment of caustic esophageal burns. Pediatr Surg Int 2010;26:619-24. [CrossRef]

11. Caliskan C, Bolukbasi H, Firat O, Yeniay L, Ozutemiz O, Korkut MA. Stricture-prevention effects of pentoxifylline and trimetazidine in an experimental corrosive esophagitis model. Akademik Gastroenteroloji Dergisi 2009;8:6-11.
12. Somuncu S, Cakmak M, Erdogan S, Caglayan O, Akman H, Kaya M. Trapidil, an inhibitor for phosphodiesterase and platelet-derived-growth factor, ameliorates corrosive esophageal burn in rats. Tohoku J Exp Med 2005;207:203-8. [CrossRef]

13. Aciksari K, Yanar HT, Hepgul G, Ozucelik DN, Yanar F, Agcaoglu O, et al. The effect of Beta-aminopropionitrile and prednisolone on the prevention of fibrosis in alkali esophageal burns: an experimental study. Gastroenterol Res Pract 2013;2013:574260. [CrossRef]

14. Wainwright M, Crossley KB. Methylene Blue--a therapeutic dye for all seasons? J Chemother 2002;14:431-43. [CrossRef]

15. Clifton J 2nd, Leikin JB. Methylene blue. Am J Ther 2003;10:289-91.

16. Dinc S, Ozaslan C, Kuru B, Karaca S, Ustun H, Alagol H, et al. Methylene blue prevents surgery-induced peritoneal adhesions but impairs the early phase of anastomotic wound healing. Can J Surg 2006;49:321-8.

17. Kalaycı MU, Eroğlu HE, Kubilay D, Soylu A, Sancak B, Uğurluoğlu $\mathrm{C}$, et al. The effects of methylene blue on adhesion formation in a rat model of experimental peritonitis. Ulus Travma Acil Cerrahi Derg 2011;17:205-9. [CrossRef]

18. Gehanno P, Guedon C. Inhibition of experimental esophageal lye strictures by penicillamine. Arch Otolaryngol 1981;107:145-7. [CrossRef]

19. Berthet B, di Costanzo J, Arnaud C, Choux R, Assadourian R. Influence of epidermal growth factor and interferon gamma on healing of oesophageal corrosive burns in the rat. Br J Surg 1994;81:395-8.

20. Ocakci A, Coskun O, Tumkaya L, Kanter M, Gurel A, Hosnuter M, et al. Beneficial effects of Ebselen on corrosive esophageal burns of rats. Int J Pediatr Otorhinolaryngol 2006;70:45-52. [CrossRef]

21. Bergman I, Loxley R. Two improved and simplified methods for the spectrophotometric determination of $\mathrm{OH}$-proline. Anal Chem 1963;35:1961-5. [CrossRef]

22. Numanoğlu KV, Tatli D, Bektaș S, Er E. Efficacy of keratinocyte growth factor (palifermin) for the treatment of caustic esophageal burns. Exp Ther Med 2014;8:1087-91. [CrossRef]

23. Kilincaslan $\mathrm{H}, \mathrm{Ozbey} \mathrm{H}$, Olgac $\mathrm{V}$. The effects of dimethyl sulfoxide on the acute phase of experimental acid and alkali corrosive esophageal burns. Eur Rev Med Pharmacol Sci 2013;17:2571-7.

24. Raghavendran K, Davidson BA, Helinski JD, Marschke CJ, Manderscheid P, Woytash JA, et al. A rat model for isolated bilateral lung contusion from blunt chest trauma. Anesth Analg 2005;101:1482-9.

25. Culo F, Sabolović D, Somogyi L, Marusić M, Berbiguier N, Galey L. Anti-tumoral and anti-inflammatory effects of biological stains. Agents Actions 1991;34:424-8. [CrossRef]

26. Montz FJ, Holschneider CH, Bozuk M, Gotlieb WH, Martinez-Maza O. Interleukin 10: ability to minimize postoperative intraperitoneal adhesion formation in a murine model. Fertil Steril 1994;61:1136-40.

27. Kilincaslan H, Karatepe HO, Kilic E, Aydogdu I, Gedik AH, Olgac V, et al. Beneficial effects of methylene blue on the acute phase of corrosive esophageal burn in rats. Eur J Pediatr Surg 2015;25:299-304. [CrossRef]

28. Howell JM, Dalsey WC, Hartsell FW, Butzin CA. Steroids for the treatment of corrosive esophageal injury: a statistical analysis of past studies. Am J Emerg Med 1992;10:421-5. [CrossRef]

29. Şen Tanrıkulu C, Tanrikulu Y, Kılınç F, Bahadır B, Can M, Köktürk F. Beneficial effects of garlic (Allium sativum) oil in experimental corrosive esophageal burns effects of garlic oil in esophageal burns. Ulus Travma Acil Cerrahi Derg 2017;23:181-7. [CrossRef]

30. Günel E, Cağlayan F, Cağlayan O, Akillioğlu I. Reactive oxygen radical levels in caustic esophageal burns. J Pediatr Surg 1999;34:405-7.

31. Evora PR, Ribeiro PJ, Vicente WV, Reis CL, Rodrigues AJ, Menardi AC, et al. Methylene blue for vasoplegic syndrome treatment in heart surgery: fifteen years of questions, answers, doubts and certainties. Rev Bras Cir Cardiovasc 2009;24:279-88. [CrossRef]

32. Salaris SC, Babbs CF, Voorhees WD 3rd. Methylene blue as an inhibitor of superoxide generation by xanthine oxidase. A potential new drug 
for the attenuation of ischemia/reperfusion injury. Biochem Pharmacol 1991;42:499-506. [CrossRef]
33. Windholz M, Budavari S. The Merck index: an encyclopedia of chemicals, drugs, and biologicals. 10th ed. Rahway, NJ: Merck\&Co,1983.

\title{
DENEYSEL ÇALIŞMA - ÖZET
}

\section{Korozif özefagus yanıklarında metilen mavisinin koruyucu ve anti-enflamatuvar etkisi: Deneysel çalışma \\ Dr. Ceren Şen Tanrıkulu, ${ }^{1}$ Dr. Yusuf Tanrıkulu, ${ }^{2}$ Dr. Fahriye Kılınç, ${ }^{3}$ Dr. Burak Bahadır, ${ }^{4}$ Dr. Murat Can, ${ }^{5}$ Dr. Fürüzan Köktürk, ${ }^{6}$ Dr. Ayşe Kefeli ${ }^{7}$}

\author{
1Sağlık Bilimleri Üniversitesi, Konya Eğitim ve Araştırma Hastanesi, Acil Tıp Anabilim Dalı, Konya \\ ${ }^{2}$ KTO Karatay Üniversitesi Tıp Fakültesi, Genel Cerrahi Anabilim Dalı, Konya \\ ${ }^{3}$ Necmettin Erbakan Üniversitesi Tıp Fakültesi, Patoloji Anabilim Dalı, Konya \\ ${ }^{4}$ Bülent Ecevit Üniversitesi Tıp Fakültesi, Patoloji Anabilim Dalı, Zonguldak \\ ${ }^{5}$ Bülent Ecevit Üniversitesi Tıp Fakültesi, Biyokimya Anabilim Dalı, Zonguldak \\ ${ }^{6}$ Bülent Ecevit Üniversitesi Tıp Fakültesi, Biyoistatistik Anabilim Dalı, Zonguldak \\ ${ }^{7}$ Gaziosmanpaşa Üniversitesi Tıp Fakültesi, Gastroenteroloji Bilim Dalı, Tokat
}

AMAÇ: Gelişmekte olan ülkelerde daha sık görülen ve korozif madde yutulmasına bağı oluşan özefageal yanıkları kısa dönemde özefagus perforasyonuna ve uzun dönemde darlık oluşmasına neden olmaktadır. Korozif özefagus yanıklarında tedavinin asıl amacı özefagusta darlık oluşumunu önlenmektir. Biz, bu çalışmada korozif özefagus yanıklarının tedavisinde metilen mavisinin (MB) antienflamatuvar ve koruyucu etkisini araştırmayı amaçladık.

GEREÇ VE YÖNTEM: Çalışmada 28 sıçan kullanııdı ve sıçanlar rastgele dört eşit gruba ayrıldı; I. grup (Sham), 2. grup (kontrol), 3. grup (topikal tedavi) ve 4. grup (topikal ve sistemik tedavi). Sham grubu hariç diğer gruplara özefageal yanık oluşturmak için sodyum hidroksit $(\mathrm{NaOH})$ verildi. Ek olarak, ikinci gruba normal salin, 3. gruba topikal metilen mavisi ve 4. gruba topikal ve sistemik metilen mavisi verildi.

BULGULAR: Hidroksiprolin seviyeleri her bir tedavi grubunda kontrol grubuna göre daha düşüktü ( $p=0.005$ grup 3'e göre, $p=0.00$ grup 4'e göre). Tümör nekrozis faktör- $\alpha$ seviyelerine göre gruplar arasında fark yoktu. Tedavi gruplarına ait stenoz indeksleri kontrol grubuna göre daha düşüktü ( $p=0.016$ grup 3'e göre, $p=0.015$ grup 4'e göre). Histopatolojik hasar skoru kontrol grubu ile karşılaştıııldığında grup 4'te belirgin olarak daha düşüktü $(p=0.05)$.

TARTIŞMA: Metilen mavisi korozif özefageal yanıkların neden olduğu doku hasarını tedavi etmede ve özefageal stenozu önlemede etkilidir. Korozif özefageal yanıklardaki komplikasyon oranları yanık esnasında kullanılan metilen mavisi ile azaltılabilir.

Anahtar sözcükler: Metilen mavisi; korozif özefagus yanı̆̆ı; kostik yanık; stenoz indeksi; TNF- $\alpha$.

Ulus Travma Acil Cerrahi Derg 2019;25(4):317-323 doi: 10.5505/tjtes.2018.58506 